\title{
POŠTA
}

TELEKOMUNIKÁCIE A

ELEKTRONICKY OBCHOD

\section{ZÁSAHY ŠTÁTU V OBLASTI POLITIKY HOSPODÁRSKEJ SÚŤAŽE NA TRHU ELEKTRONICKÝCH KOMUNIKÁCIÍ}

\author{
Lucia Madleňáková*
}

\section{Úvod}

V dôsledku nedokonalosti štruktúry trhov v niektorých odvetviach je nevyhnutné aby vláda pristupovala $\mathrm{k}$ zásahom do týchto odvetví. Tie pritom môžu mat' rôznu formu či rozsah, pričom vol'ba konkrétneho zásahu či opatrenia musí zodpovedat' naplńaniu základných ekonomických funkcií štátu. Nedokonalosti trhovej štruktúry v sektore elektronických komunikácií sú prejavom ponuky a dopytu predovšetkým vo väzbe na používané technológie, produkty, výrobné faktory a pod.

\section{Ochrana hospodárskej sút’aže}

Hospodársku sút’až možno definovat' ako súbor pravidiel správania podnikatel'ských subjektov na trhu, ktorých dodržiavanie je predpokladom d'alšieho hospodárskeho rastu a rozvoja. Efektívne fungovanie hospodárskej sút'aže je možné len za predpokladu, že podnikatel'ské subjekty pôsobiace na danom trhu môžu robit' svoje obchodné rozhodnutia samostatne. Je však potrebné tiež vylúčit', prezrádzanie vlastných podnikatel'ských zámerov konkurencii. Politika hospodárskej sút'aže sa v zmysle platnej legislatívy sústred’uje na štyri základné oblasti: [1]

- eliminácia dohôd obmedzujúcich hospodársku sút’až a zneužívanie dominantného postavenia na trhu

- kontrola podnikových fúzií

- liberalizácia monopolných sektorov hospodárstva

- monitorovanie štátnej podpory

O zneužívaní dominantného postavenia možno hovorit’ vtedy, ak si dominantný hráč udržiava alebo zväčšuje svoje postavenie na trhu využívaním obchodných praktík, ktoré obmedzujú hospodársku sút'až.

Pri posudzovaní správania sa podnikatel'ov v dominantnom postavení je dôležité posudzovat' ako predmetné konanie poškodzuje sútaž, ako sa oslabuje existujúca úroveň konkurencie, aké sú priame alebo nepriame dopady posudzovaného správania sa na konkurentov alebo tretie strany, či zámerom dominanta je tzv. vykoristovanie alebo

\footnotetext{
* Ing. Lucia Madleňáková, PhD., Žilinská univerzita v Žiline, Fakulta Prevádzky a ekonomiky dopravy a spojov, Katedra spojov, Univerzitná 1, 01026 Žilina tel.: $+421 / 41 / 5133125$, fax: $+421 / 41 / 5655615$ e-mail: Lucia.Madlenakova@,fpedas.uniza.sk
} 
vylučovanie, alebo či posudzované konanie predstavuje legitímnu reakciu na konkurenciu, či praktika je proporcionálna jeho legitímnemu záujmu a pod.

Zákaz zneužívania dominantného postavenia sa týka unilaterálnych výstupov dominantných spoločností, ktoré majú charakter zneužívania svojho takpovediac „výsadného/významného“ postavenia. Správanie sa dominantných hráčov na trhu môže mat' charakter vykorist'ovatel'ský, vylučovací, alebo môže byt' kombináciou oboch. Všeobecne sa považujú za zneužívajúce také praktiky dominantných spoločností, ktoré sa zvyčajne odchyl'ujú od štandardných spôsobov pôsobenia podnikatel'ov na konkurenčných trhoch a ktoré sú spôsobilé ovplyvňovat' štruktúru trhu zoslabovaním, resp. elimináciou už existujúceho stupňa sút’aže. Existencia reálneho alebo potenciálneho efektu prezentujúceho prekážku alebo oslabenie existujúcej úrovne konkurencie je zvyčajne nevyhnutným atribútom pre kvalifikáciu konania ako zneužívania dominantného postavenia na príslušnom trhu.

Všeobecne aplikačná prax potvrdzuje, že zneužívanie dominantného postavenia a jeho následky sa nemusia vždy prejavit' len na tom istom trhu, ale i na trhoch susediacich a nadväzujúcich. Komplexnost' posudzovania správania sa dominantných spoločností vyžaduje potrebu objektívneho posúdenia a identifikácie výstupu, ktorý $\mathrm{v}$ dôsledku svojho reštriktívneho charakteru vykazuje znaky zneužívania od legitímneho sút’ažného výstupu takýchto spoločností.[7]

K obmedzovaniu hospodárskej sút’aže môže dochádzat' aj v dôsledku podnikových fúzií. Kým na jednej strane spájanie sa síl môže viest' k rozširovaniu trhov s pozitívnym prínosom pre zákazníka, na druhej strane existujú fúzie poškodzujúce zákazníka. K obmedzovaniu hospodárskej sút'aže dochádza obvykle vtedy, ked' sa vytvorí alebo posilní dominantný hráč. Je pravdepodobné, že takto dôjde k poškodeniu spotrebitel'ov v dôsledku vyšších cien, obmedzeného výberu alebo menšej inovácie. Zvýšená hospodárska sút'až v rámci európskeho spoločného trhu a globalizácia patria medzi faktory, ktoré lákajú spoločnosti, aby spojili svoje sily. Takéto reorganizácie sú vítané vtedy, ked' neprekážajú hospodárskej sút'aži, a teda dokážu zvyšovat' konkurencieschopnost' európskeho priemyslu zlepšovaním podmienok rastu a zvyšovaním životnej úrovne v EÚ.

Ďalším dôležitým princípom fungovania hospodárskej sút’aže je aj liberalizácia monopolov. Existencia monopolov spravidla vedie k vysokým cenám a nižšej kvalite služieb. $\mathrm{Z}$ tohto dôvodu EÚ zaviedla do takýchto monopolných odvetví sút'až.

Otvorenie trhov konkurencii umožnilo spotrebitel'om t’ažit' z nižších cien a nových služieb, ktoré sú zvyčajne efektívnejšie a priaznivejšie voči spotrebitel'ovi než predtým. To pomáha zvyšovat' konkurencieschopnost' nášho hospodárstva.

Pod pojmom ,štátna pomoc“ možno rozumiet' pomoc poskytovanú zo štátnych, resp. verejných zdrojov, ktorá zároveň zvýhodňuje určitých podnikatel'ov, podniky, výrobu určitého tovaru alebo poskytovania služby. Poskytovanie štátnej pomoci je súčast'ou oblasti ochrany hospodárskej sút’aže. Medzi základné formy poskytovania štátnej pomoci možno zaradit' daňové úl'avy, dotácie, oslobodenie od úrokov, výhodné pôžičky, výhody v oblasti sociálnych systémov, prevzatie záruk, bezplatné alebo vel'mi výhodné prenajímanie budov a pozemkov, výhodné podmienky na dodávku tovaru atd’.[2]

Štátna podpora sa poskytuje za účelom podpory rozvoja alebo zmiernenie t’ažkostí. Na prvý pohl'ad môže štátna podpora vyzerat' vel'mi prospešne, najmä z hl'adiska príjemcu. Často sa však docieli iba odklad nevyhnutnej reštrukturalizácie bez toho, aby príjemcovi pomohla znova získat' stratenú konkurencieschopnost'. Je to nástroj, s ktorým je potrebné narábat' vel'mi opatrne, aby na druhej strane nepôsobil skôr ochranársky a neviedol práve k zneužívaniu dominantného postavenia.

Uvedené princípy ochrany hospodárskej sút’aže sa výrazne týkajú práve odvetvia elektronických komunikácií. Je to sektor, ktorý sa v súčasnej dobe vyznačuje rýchlymi technologickými, ale aj trhovými zmenami. V nedávnej minulosti sa tento trh vyznačoval 
existenciou prirodzeného monopolu. Trh elektronických komunikácií v SR je plne liberalizovaný od roku 2003, konkurencia sa v podstate ešte len začína rozvíjat' a na väčšine trhov elektronických komunikácií prevláda vplyv incumbenta. Je teda potrebné vhodnými reštrikčnými opatrenia a nástrojmi ochrany hospodárskej sút'aže podporit' rozvoj konkurencie v tomto odvetví.

\section{Regulácia v odvetví elektronických komunikácií}

Reguláciu možno chápat' ako proces založený na zákonoch, ktoré majú bud' reštriktívny alebo kontrolný charakter vzhl'adom na rozhodnutia prijímané objektmi regulácie.

Pri zdôvodňovaní potreby regulácie sa často ekonómovia odvolávajú na existenciu viacerých príčin, ktoré sú základom regulačných zásahov. K hlavným príčinám možno zaradit': [1]

a) existenciu prirodzených monopolov, pre ktoré je charakteristické dosahovanie úspor z rozsahu a zo sortimentu, prípadne úspor zo sietí. Úspory sa pritom premietajú do klesajúcej krivky priemerných celkových nákladov, pričom hraničné náklady sú dlhodobo pod priemernými nákladmi,

b) požadovanie všeobecnosti služby za „rozumnú cenu“, čo vedie ku krížovému subvencovaniu. Toto je možné zabezpečit’ len v tom prípade, ak firma poskytujúca službu nie je vystavená cenovej konkurencii a možnosti vol'ného vstupu nových konkurenčných firiem $\mathrm{z}$ iných trhov.

c) zabezpečenie ochrany pred samovol'ným zánikom konkurencie, čo vyplýva z existencie napr. aj ochrany spotrebitel'a.

V oblasti elektronických komunikácií možno hovorit' o dvoch formách regulácie a to:

- ex ante (pred vznikom skutočnosti)

- ex post (po vzniku skutočnosti).

\section{Regulácia ex ante v elektronických komunikáciách}

Reguláciu ex-ante v Slovenskej Republike zabezpečuje Telekomunikačný úrad SR. Jeho úlohou je zabezpečit' plnenie povinností podporujúcich sút'až, rozvoj spoločného trhu EÚ, ochrana záujmov koncových používatel’ov, mimosúdne riešenie sporov a zabezpečovanie dodržiavania požiadaviek na výkon činnosti, ktoré vyplývajú zo zákona č. 610/2003 Z. z. o elektronických komunikáciách v znení neskorších predpisov, všeobecne záväzných predpisov, technických noriem, medzinárodných zmlúv, ktorými je SR viazaná a z odporúčaní medzinárodných organizácií v tejto oblasti.

Telekomunikačný úrad pri regulácii zabezpečuje, aby nedochádzalo k narušovaniu alebo obmedzovaniu sút’aže a diskriminácii podnikov, podporuje efektívne investície do kvalitnej a modernej infraštruktúry, dbá na zachovanie celistvosti a bezpečnosti verejných sietí. Vytvára podmienky, aby všetci koncoví užívatelia mali prístup k univerzálnej službe, a dbá na maximálny prospech užívatel'ov, najmä zdravotne postihnutých uživatel'ov, v súvislosti s možnost'ou výberu služby, ceny a kvality.[10]

V roku 2004 začal telekomunikačný úrad vykonávat' analýzy relevantných trhov s ciel'om zistit', či je na nich efektívna sút'až. V prípade neexistencie efektívnej sút'aže, po skončení konzultácií určí rozhodnutím významný podnik a uloží mu povinnosti (v zmysle zákona č. 610/2003 Z. z.), ktorých ciel'om je podpora efektívnej sút’aže a rozvoj vnútorného trhu. Povinnosti uložené významnému podniku musia vychádzat' zo zisteného stavu a musia byt' oprávnené a primerané účelu a princípom regulácie, ktorými sú predovšetkým podpora efektívnej sút'aže a rozvoj vnútorného trhu. V prípade, že na danom trhu už významný podnik určený je, telekomunikačný úrad mu jeho existujúce povinnosti ponechá, zmení prípadne doplní za účelom dosiahnutia efektívnej sút’aže. [4] 
V prípade, že sa analýzou zistí, že na danom relevantnom trhu efektívna sút’až existuje, Telekomunikačný úrad nesmie uložit' žiadnu povinnost', resp. musí rozhodnutím zrušit' existujúce povinnosti, pričom týmto rozhodnutím sa ruší i určenie významného podniku.

\section{Regulácia ex post v elektronických komunikáciách}

Reguláciu ex-post v oblasti elektronických komunikácií zabezpečuje Protimonopolný úrad SR, ktorého hlavným poslaním je chránit' a podporovat' hospodársku sút’až, vytvárat' podmienky pre jej d'alší rozvoj, ako aj zamedzovat' vzniku a udržiavaniu monopolného alebo dominantného postavenia podnikatel'ských subjektov, pokial' znemožňuje, alebo obmedzuje hospodársku sút’až. Jeho kompetencie sú upravené zákonom ako rozhodujúcim nástrojom zabezpečenia systému ochrany a tvorby konkurencie najmä v oblastiach: [7]

- ak úrad považuje dohodu medzi podnikatel'mi za takú, ktorá obmedzuje sút'až, vydáva rozhodnutie o povinnosti zdržat' sa plnenia takejto dohody,

- ak dochádza ku zneužitiu dominantného postavenia, úrad vydáva rozhodnutie o povinnosti zdržat' sa takéhoto konania,

- úrad vydáva rozhodnutia o koncentrácii,

- úrad požaduje nápravu od orgánov štátnej správy a obcí, ak tieto obmedzujú hospodársku sút'až,

- podpory hospodárskej sút’aže v procese privatizácie,

- podiel'a sa na identifikácii a odstraňovanie ostatných bariér vstupu na trh,

- zabezpečuje propagáciu princípov ochrany hospodárskej sút’aže,

- zastupuje SR pri medzinárodných rokovaniach a dohodách v oblasti hospodárskej sút'aže.

\section{Konkurencia na trhu elektronických komunikácií v SR a ČR}

S implementáciou nového regulačného rámca EÚ pre oblast' elektronických komunikácií došlo k výraznému posunu v možnosti aplikovat' reguláciu a to smerom $\mathrm{k}$ uplatňovaniu princípov komunitárneho sút’ažného práva. Pôvodný regulačný rámec neumožňoval posudzovanie regulovaných trhov v zmysle princípov sút’ažného práva. Naopak, dnes sa vyžaduje podrobné mapovanie podmienok hospodárskej sút’aže existujúcej na každom jednotlivom relevantnom trhu, t.j. nie len na základe výpočtu trhového podielu ale tiež v zmysle hodnotenia d'alších kritérií.

\section{Stav konkurencie $v$ SR}

Ako už bolo vyššie spomenuté, Telekomunikačný úrad SR, ako regulátor elektronických komunikácií, začal uskutočňovat' analýzy relevantných trhov, ktorých účelom je identifikovanie podnikov pôsobiacich na danom relevantnom trhu, d’alej posúdenie, či na danom trhu existuje významný podnik, ktorý podl'a zákona sám alebo spoločne s inými podnikmi má na tomto trhu také postavenie, že nie je vystavený efektívnej sútaži a ekonomický vplyv mu v podstatnom rozsahu dovol'uje správat' sa nezávisle od konkurentov a užívatel'ov a nakoniec uloženie povinností podniku s významným vplyvom na danom trhu. Analýza relevantných trhov je rozdelená do oblasti maloobchodných a vel'koobchodných trhov. Maloobchodným trhom pritom rozumieme trh takých elektronických komunikačných služieb, ktoré poskytuje podnik koncovým uživatel'om. Vel'koobchodným trhom sa rozumie trh takých služieb, ktoré poskytuje podnik inému podniku. Zoznam maloobchodných a vel'koobchodných trhov, na ktorých je vykonávaná analýza a určovaný významný podnik je dostupný na http://www.teleoff.gov.sk/sk/Sutaz/analyza.html.[13]

Na základe doposial' vykonaných analýz maloobchodných relevantných trhov môžeme k 1.3.2007 výsledky zhrnút' do nasledovnej tabul'ky. 
Tabul'ka č. 1 Výsledky analýzy maloobchodných trhov v SR

\begin{tabular}{|c|c|c|c|c|}
\hline $\begin{array}{c}\text { Maloobchodné } \\
\text { trhy }\end{array}$ & $\begin{array}{c}\text { Podnik s významným } \\
\text { postavením na trhu }\end{array}$ & $\begin{array}{c}\text { Podiel podniku s } \\
\text { významným postavením } \\
\text { na danom trhu }\end{array}$ & $\begin{array}{c}\text { Sút'až na } \\
\text { danom trhu }\end{array}$ & $\begin{array}{c}\text { Potenciálna } \\
\text { konkurencia na } \\
\text { danom trhu }\end{array}$ \\
\hline 1. & Slovak Telecom, a.s. & $100 \%$ & neexistuje & neexistuje \\
\hline 2. & Slovak Telecom, a.s. & $100 \%$ & neexistuje & neexistuje \\
\hline 3. & Slovak Telecom, a.s. & $100 \%$ & neexistuje & existuje \\
\hline 4. & Slovak Telecom, a.s. & $100 \%$ & neexistuje & existuje \\
\hline 5. & Slovak Telecom, a.s. & $100 \%$ & neexistuje & existuje \\
\hline 6. & Slovak Telecom, a.s. & $100 \%$ & neexistuje & existuje \\
\hline 7. & Slovak Telecom, a.s. & $52,5 \%$ & neexistuje & existuje* \\
\hline
\end{tabular}

* Slovak Telecom, a.s. je jedinou spoločnost’ou poskytujúcou prenájom celého súboru prenajatých okruhov v zmysle definície maloobchodného trhu č. 7. Vlastníctvo celoplošnej elektronickej komunikačnej siete vrátane účastníckych vedení jej dáva výraznú konkurenčnú výhodu oproti ostatným podnikom pôsobiacim na danom trhu.

Z výsledkov analýz maloobchodných trhov vyplýva, že na všetkých vymedzených relevantných trhoch má významné postavenie práve spoločnost' Slovak Telecom, a.s. a teda nie je vystavená efektívnej sút’aži a konkurencii. Práve $\mathrm{z}$ tohto dôvodu uložil regulátor významnému podniku povinnosti v zmysle $\S 18$ - 28 zákona č. 510/2003 Z.z. o elektronických komunikáciách.

V prípade vel'koobchodných trhov, bola analýza relevantných trhov vykovaná na zatial' na 9 trhoch z celkového počtu jedenást'. Výsledok je zhrnutý v tabul'ke č. 2.

Tabul'ka č. 2 Výsledky analýzy vel'koobchodných trhov v SR

\begin{tabular}{|c|c|c|c|c|}
\hline $\begin{array}{l}\text { Vel'koobchodné } \\
\text { trhy }\end{array}$ & $\begin{array}{c}\text { Podnik(y) s } \\
\text { významným } \\
\text { postavením na trhu }\end{array}$ & $\begin{array}{l}\text { Podiel podniku s významným } \\
\text { postavením na danom trhu }\end{array}$ & $\begin{array}{c}\text { Sút'až na danom } \\
\text { trhu }\end{array}$ & $\begin{array}{l}\text { Potenciálna } \\
\text { konkurencia na } \\
\text { danom trhu }\end{array}$ \\
\hline 1. & Slovak Telecom, a.s. & $100 \%$ & neexistuje & neexistuje \\
\hline 2. & Slovak Telecom, a.s. & $100 \%$ & neexistuje & neexistuje \\
\hline 3. & Slovak Telecom, a.s. & $85 \%$ & obmedzená & existuje \\
\hline 4. & Slovak Telecom, a.s. & $100 \%$ & neexistuje & neexistuje \\
\hline 5. & Slovak Telecom, a.s. & $73,94 \%-80,17 \% *$ & nie je efektívna & existuje \\
\hline 6. & Slovak Telecom, a.s. & $80 \%$ & nie je efektívna & existuje \\
\hline 7. & \multicolumn{4}{|c|}{ Trh zatial’ nebol analyzovaný } \\
\hline 8. & T-Mobile, Orange & T-Mobile $-45 \%$, Orange- $55 \%$ & neexistuje & neexistuje \\
\hline 9. & T-Mobile, Orange & T-Mobile $-45 \%$, Orange- $55 \%$ & neexistuje & neexistuje \\
\hline 10. & \multicolumn{4}{|c|}{ Trh zatial' nebol analyzovaný } \\
\hline 11. & Slovak Telecom, a.s. & $\begin{array}{l}99 \% \text { televízne vysielanie } \\
89 \% \text { rozhlasové vysielanie }\end{array}$ & nie je efektívna & existuje \\
\hline
\end{tabular}

* vel'kost' trhového podielu spoločnosti Slovak Telekom, a. s. na vel'koobchodnom trhu č. 5 vyjadrená prostredníctvom počtu účastníkov pripojených rýchlost’ou vyššou ako $256 \mathrm{kbit} / \mathrm{s}$ sa v období od 30.6 .2004 do 31.12.2005, je teda zrejmý nárast trhového podielu spoločnosti Slovak Telekom, a.s.. Telekomunikačný úrad v horizonte dvoch rokov nepredpokladá výrazný pokles trhového podielu Spoločnosti Slovak Telecom, a.s..

\section{Stav konkurencie v $\check{C} R$}

Zákon o elektronických komunikáciách s implementovaným novým regulačným rámcom nadobudol účinnost' v Českej republike 1. mája 2005, teda až ku dňu vstupu do EÚ. Národným regulačným úradom sa stal Český telekomunikačný úrad (ČTú), ktorý začal vykonávat' analýzy relevantných trhov v septembri 2005. 
11. augusta 2006 Európska komisia (EK) ukončila preverovanie výsledkov analýzy jednotlivých relevantných trhov, vyjadrila s nimi súhlas, čo umožnilo Českému telekomunikačnému úradu ich vydanie. Týmto krokom ČTÚ splnil svoje záväzky voči EK, týkajúce sa implementácie nového regulačného rámca $v$ oblasti elektronických komunikácií. Výsledky všetkých 18 analýz relevantných trhov sú zverejnené na internetovej stránke Českého telekomunikačného úradu. [12]

Tabul'ka č. 3 Výsledky analýzy relevantných trhov v ČR

\begin{tabular}{|c|c|c|c|}
\hline $\begin{array}{l}\text { Relevantný } \\
\text { trh č. }\end{array}$ & $\begin{array}{l}\text { Podnik s dominantným } \\
\text { postavením na trhu }\end{array}$ & $\begin{array}{c}\text { Podiel podniku s významným postavením na } \\
\text { danom trhu }\end{array}$ & $\begin{array}{l}\text { Sút’až na danom } \\
\text { trhu }\end{array}$ \\
\hline 1. & ČESKÝ TELEKOM, a.s. & viac ako $75 \%$ & nie je efektívna \\
\hline 2. & ČESKÝ TELEKOM, a.s. & viac ako $75 \%$ & nie je efektívna \\
\hline 3. & ČESKÝ TELEKOM, a.s. & viac ako $75 \%$ & nie je efektívna \\
\hline 4. & ČESKÝ TELEKOM, a.s. & viac ako $50 \%$ & nie je efektívna \\
\hline 5. & ČESKÝ TELEKOM, a.s. & viac ako $50 \%$ & nie je efektívna \\
\hline 6. & - & $\begin{array}{c}\text { neexistuje podnik so samostatnou významnou } \\
\text { trhovou silou }\end{array}$ & je efektívna \\
\hline 7. & ČESKÝ TELEKOM, a.s. & viac ako $50 \%$ & nie je efektívna \\
\hline 8. & ČESKÝ TELEKOM, a.s. & viac ako $75 \%$ & nie je efektívna \\
\hline 9. & $*$ & $100 \%$ & nie je efektívna \\
\hline 10. & - & $\begin{array}{c}\text { neexistuje podnik so samostatnou významnou } \\
\text { trhovou silou }\end{array}$ & je efektívna \\
\hline 11. & ČESKÝ TELEKOM, a.s. & $98,39 \%$ & nie je efektívna \\
\hline 12. & ČESKÝ TELEKOM, a.s. & viac ako $75 \%$ & nie je efektívna \\
\hline 13. & ČESKÝ TELEKOM, a.s. & viac ako $50 \%$ & nie je efektívna \\
\hline 14. & 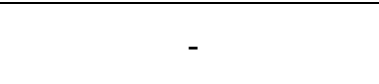 & $\begin{array}{l}\text { neexistuje podnik so samostatnou významnou } \\
\text { trhovou silou }\end{array}$ & je efektívna \\
\hline 15. & - & $\begin{array}{c}\text { neexistuje významný podnik, ani spoločný } \\
\text { významný vplyv }\end{array}$ & je efektívna \\
\hline 16. & $* *$ & $100 \%$ & nie je efektívna \\
\hline 17. & - & $\begin{array}{l}\text { neexistuje podnik so samostatnou významnou } \\
\text { trhovou silou }\end{array}$ & je efektívna \\
\hline 18. & $\begin{array}{l}\text { RADIOKOMUNIKACE, } \\
\text { a.s. }\end{array}$ & $100 \%$ & nie je efektívna \\
\hline
\end{tabular}

* Analýza identifikovala prítomnost' prekážok trvalého charakteru brániacich vstupu na trh č. 9 (ukončenie volania), a to vzhl'adom na skutočnost', že ukončit' volanie môže len ten poskytovatel', v ktorého sieti sa volané účastnícke číslo nachádza. Z toho vyplýva, že každý poskytovatel' pôsobiaci na tomto trhu $\mathrm{v}$ jednotlivých verejných telefónnych siet'ach poskytovaných $\mathrm{v}$ pevnom mieste je poskytovatelom s významnou trhovou silou. Aj napriek tomu, ČTÚ udelil povinnosti v zmysle zákona o elektronických komunikáciách len spoločnosti ČESKÝ TELEKOM, a.s. a to na základe uplatnenia zásady proporcionality na trhu.

** Analýza identifikovala prítomnost' prekážok trvalého charakteru brániacich vstupu na trh a to z dôvodu, že ukončit' volanie môže len ten poskytovatel' v ktorého sieti sa účastnícke číslo nachádza. Z toho vyplýva, že každý poskytovatel pôsobiaci na relevantnom trhu č. 16 ( ukončenie volania vo verejných mobilných telefónnych siet’ach) má $100 \%$ podiel vo vlastnej sieti a je teda poskytovatel’om s významnou trhovou silou.

Na základe výsledkov uvedených v tabul'ke č. 3 možno konštatovat', že na väčšine analyzovaných trhov má ešte stále významné postavenie incumbent, a to ČESKÝ TELEKOM, a.s.. Na týchto trhoch neexistuje efektívna sút'až a zatial nápravné opatrenia uložené a vykonané v zmysle platnej národnej legislatívy či práva ES v oblasti hospodárskej sút’aže nepostačujú $\mathrm{k}$ riešeniu daného problému. Práve na základe výsledkov jednotlivých analýz 
môže ČTÚ pokračovat' vo vydávaní regulačných rozhodnutí (určit' podmienky podnikania za základe ex-ante regulácie) všade tam, kde bude nutné zareagovat’ na zlyhávanie trhu.

\section{Spolupráca Telekomunikačného úradu SR s Protimonopolným úradom}

Telekomunikačný úrad SR spolu s Protimonopolným úradom SR navzájom úzko spolupracujú a vychádzajú si v ústrety, s úmyslom zabezpečit' efektívnu konkurenciu na trhoch elektronických komunikácií.

Protimonopolný úrad spolu s Telekomunikačným úradom majú vytvorenú dohodu, ktorá vyjadruje ich spoločný zámer spolupracovat' vo veciach spoločného záujmu, rešpektujúc práva a povinnosti, ktoré obom orgánom vyplývajú $\mathrm{z}$ právnych predpisov $\mathrm{s}$ ciel’om zabezpečit':

- koordinovaný výkon vecných pôsobností Protimonopolného úradu SR a Telekomunikačného úradu SR v záujme zabránenia vzniku pozitívnych alebo negatívnych kompetenčných konfliktov, najmä však vydaniu navzájom si kolidujúcich rozhodnutí, rovnakú interpretáciu pojmov používaných v zákonoch a iných všeobecne záväzných právnych predpisoch týkajúcich sa hospodárskej sút'aže a oblasti telekomunikácií,

- spoluprácu pre stanovenie konzistentných postupov pri riešení prípadov v oblasti elektronických komunikácií,

- vzájomnú informovanost' o veciach, ktoré sa týkajú zneužitia dominantného postavenia, dozoru nad podnikatel'mi s dominantným postavením na relevantnom trhu v oblasti elektronických komunikácií podla zákona o ochrane hospodárskej sút’aže, alebo na telekomunikačnom trhu podl'a zákona o elektronických komunikáciách a regulácie v oblasti elektronických komunikácií.

Napriek tejto dohode a ich vzájomnej spolupráci však dochádza na trhoch elektronických komunikácií $\mathrm{k}$ nejednoznačnosti $\mathrm{v}$ pôsobení Telekomunikačného a Protimonopolného úradu SR, čo využíva podnik s dominantným postavením na trhu, na ktorom sa preukázala jeho dominancia. Aj ked' Telekomunikačný úrad SR udelí povinnosti, resp. Protimonopolný úrad SR udelí pokutu príslušnému podniku, ktorí zneužíva dominantné postavenie na trhu, nie vždy sa tieto opatrenia úradov aj naozaj uskutočnia. A to je práve spôsobené nejasne vymedzenými kompetenciami príslušných orgánov, čo samozrejme využíva incumbent pevných liniek a odvoláva sa proti týmto rozhodnutiam. Preukázanie opodstatnenosti jednotlivých opatrení či už Telekomunikačného alebo Protimonopolného úradu potom rieši súd, na výsledok ktorého sa musí čakat' aj niekol'ko mesiacov. Všetky odvolávania a súdne priet’ahy tak spomal'ujú efektívnu konkurenciu na trhoch elektronických komunikácií. [3]

\section{Možnosti d'alšieho vývoja v oblasti elektronických komunikácií 6.1 Vplyv nového regulačného rámca EÚ na d'alší vývoj elektronických komunikácií}

Nový regulačný rámec pre elektronické komunikácie, ktorý bol implementovaný do slovenského právneho prostredia pri vstupe Slovenskej republiky do Európskej únie, prispieva $\mathrm{k}$ vytváraniu prostredia, ktoré podporuje inováciu a investície $\mathrm{v}$ sektore informačných a komunikačných technológií. Stavia na princípe technologickej neutrality, aby tak mohol reagovat' na výzvy technologického rozvoja $\mathrm{v}$ budúcnosti a bol dostatočne flexibilný pri zásobovaní každého jednotlivého trhu. Rovnako podporuje hospodársku sút'až medzi infraštruktúrami a rôznymi technologickými platformami, čím následne dochádza $\mathrm{k}$ zlepšovaniu dostupnosti obsahu vo vzt’ahu k občanom. V konečnom dôsledku tento rámec 
prispieva k stimulácii výskumu a novým investíciám zo strany nových subjektov, ako aj už existujúcich operátorov.

Európska komisia zohráva významnú úlohu $\mathrm{v}$ rámci zabezpečovania dodržiavania koherentného prístupu národných regulačných orgánov pri analýze a regulovaní trhov $\mathrm{s}$ elektronickými komunikáciami. Nový regulačný balík, vytvára mechanizmus pre konzultácie a koordináciu v súvislosti s niektorými národnými regulačnými opatreniami, vrátane možnosti Komisie uplatnit' právo veta, s ciel'om dosiahnut' jednotnost' a zachovat' jednotný trh. Ako už bolo ukázané, EK bude aj nad’alej využívat' tento silný nástroj, ktorý jej zveril Európsky parlament a Rada, a bude pri tom postupovat' čo najtransparentnejšie.[6]

S ciel'om d'alšej podpory konsolidácie jednotného trhu a dosahovania jednotnosti pri uplatňovaní regulačného rámca vytvorila EK Skupinu európskych regulátorov (ERG), ktorú tvoria národné regulačné orgány každého členského štátu. Táto skupina zohráva významnú úlohu v komunikácii medzi jednotlivými národnými orgánmi každodenne uplatňujúcimi nové pravidlá vo svojich krajinách a Európskou komisiou, ktorá dohliada na uplatňovanie rámca pre EÚ ako celok.

Rozsah spolupráce je široký, pretože ERG môže, na základe vlastnej iniciatívy alebo na požiadanie EK, poskytnút' radu a pomôct' EK vo všetkých otázkach týkajúcich sa elektronických komunikačných sietí a služieb.

\subsection{Možnosti vývoja elektronických komunikácií na Slovensku zásahmi TÚ SR}

Nový zákon o elektronických komunikáciách podstatným spôsobom zvýšil a rozšíril kompetencie Telekomunikačnému úradu SR. Tieto kompetencie umožňujú TÚ SR ukladat' podnikom určité povinnosti, čo v minulosti nebolo možné. Táto úprava mala pozitívny vplyv na rozvoj trhu $\mathrm{s}$ elektronickými komunikáciami na Slovensku a prispela $\mathrm{kjeho}$ zdynamizovaniu a úplnej liberalizácii.

Po prijatí nového zákona o elektronických komunikáciách a rozšírení kompetencií TÚ $\mathrm{SR}$, sa v tejto oblasti uskutočnilo vel'a pozitívnych zmien, ako pre alternatívnych operátorov, tak aj pre konečných spotrebitel'ov.

TÚ SR už dávnejšie začal vykonávat' analýzy relevantných trhov, ktorých uskutočňovanie nám vyplynulo $\mathrm{z}$ členstva $\mathrm{v}$ EÚ a prijatia nového regulačného rámca pre elektronické komunikácie. Napriek tomu, že sme pomerne novým členom EÚ, si počína náš telekomunikačný regulátor vel'mi dobre. K 31.03.2006 bolo uverejnených na stránkach Telekomunikačného úradu SR 12 analyzovaných relevantných trhov z celkového počtu 18 relevantných trhov. Prostredníctvom týchto analýz mohol TÚ SR identifikovat' podniky s dominantným postavením na trhu a tým im udelit’ povinnosti vyplývajúce zo zákona. Je už len otázkou času, kedy úrad dokončí zvyšné analýzy relevantných trhov, čo prispeje k d'alšiemu vývoju na trhoch elektronických komunikácií. V rámci udelených povinností dominantnému prevádzkovatel'ovi pevných sietí boli uvedené aj povinnosti uvol'nit' účastnícke vedenie alternatívnym operátorom a taktiež prepojenie sietí Slovak Telecomu, a.s. s alternatívnymi operátormi, čoho sme sa dočkali v druhej polovici roka 2005. Doteraz bolo uzatvorených trinást' zmlúv o prepojení pevných sietí alternatívnych operátorov so spoločnost'ou Slovak Telecom a.s., a dve zmluvy o prepojení pevnej siete ST, a.s. s mobilnými siet'ami, takže individuálny výber vol'by a predvol'by operátora je dostupný na Slovensku pre koncových spotrebitel'ov od roku 2005 vd'aka snahám a zásahom nášho telekomunikačného regulátora. [5]

Ďalšou krokom k vytváraniu podmienok na budovanie efektívnej konkurencie na trhu elektronických komunikácií je aj pridelenie individuálnych povolení pre zriadenie pevného bezdrôtového pripojenia (FWA) a využívanie frekvencie v pásme 3,5 GHz. Povolenie TÚ udelil štyrom alternatívnym operátorom a to Amtel Slovensko, s.r.o., GlobalTel, a.s., Telenor 
Networks, a.s. a WiMax telecom Slovakia, s.r.o., pričom v sút’aži neuspeli také spoločnosti ako Orange Slovensko a T-Mobile Slovensko. Operátori teda môžu v danom pásme zriadit' pevné bezdrôtové pripojenie (FWA), ktoré sa najčastejšie využíva na poskytovanie bezdrôtového prístupu na internet a firmám tak umožní najmä prienik do segmentu malých aj bytových zákazníkov. Tento spôsob riešenia by tak mohol byt' do určitej miery alternatívou voči účastníckemu vedeniu spoločnosti Slovak Telecom. [13]

Po vybudovaní pevného bezdrôtového pripojenia spomínanými spoločnost’ami, by mal nastat' tvrdý boj o zákazníka, a vytvorenie efektívnej a zdravej sút'aže v oblasti prístupu na internet. Spotrebitel' bude mat' viac možností výberu, a tak bude incumbent Slovak Telecom, a.s. nútený postupne znižovat' ceny, aby si udržal zákazníka.

Významným krokom $\mathrm{v}$ rozvoji elektronických komunikácií je vstup tretieho mobilného operátora na slovenský mobilný trh. Z výsledkov analýzy relevantného trhu č. 8 a č. 9 je zrejmé, že vzájomná konkurencia dvoch spoločností Orange, a.s. a T-Mobile, a.s. nepostačuje, nakol'ko oba tieto podniky majú významné postavenie. Podl'a kritérií, ktoré stanovil TÚ SR už pred zverejnením výzvy na predkladanie ponúk do výberového konania na tretieho mobilného operátora malo váhu až $50 \%$ kritérium ,prispenie účastníka $k$ posilneniu konkurenčného trhu v oblasti elektronických komunikácii" a naopak najmenšiu váhu len $5 \%$ „ponúkaná výška jednorazovej úhrady za pridelenie frekvenčných blokov“. Z troch ponúk nakoniec regulátor vydal povolenie spoločnosti Telefónica O2 Slovakia s.r.o., ktorá je povinná uviest' do prevádzky vlastnú mobilnú siet' GSM do 6 mesiacov a mobilnú siet' UMTS do 12 mesiacov od nadobudnutia právoplatnosti povolenia (povolenie vydané 7.9.2006). Telefónica O2 má pridelené frekvencie v pásmach GSM 900 a $1800 \mathrm{MHz}$, v pásme UMTS a FS 28/29 GHz. Pridelený blok frekvencií vo frekvenčnom pásme $28 / 29 \mathrm{GHz}$ je určený pre infraštruktúru verejnej mobilnej telefónnej siete GSM a UMTS systémom bod-multibod (PMP) a bod -bod (P-P). Držitel' povolenia má právo budovat' infraštruktúru siete, zriad'ovat' pevné rádiové spoje typu bod-bod (P-P) aj v iných frekvenčných pásmach, ktoré sú pre takýto účel stanovené $\mathrm{V}$ národnej tabul'ke frekvenčného spektra. Príchod tretieho mobilného operátora na trh vyvolá tlak na zvyšovanie kvality služieb, ich rozširovanie a v neposlednom rade na znižovanie cien pre koncových užívatel'ov služieb.[13]

Významným krokom k zlepšeniu služieb elektronických komunikácií by malo byt' aj zníženie poplatkov medzinárodného roamingu. V tejto oblasti sa výrazne angažuje a j EK, ktorá vyzvala k zníženiu poplatkov na úroveň prijatel'nú pre spotrebitel'a. Túto výzvu však rešpektovala len máloktorá členská krajina a roamingové poplatky tak ostali na minuloročnej úrovni, v niektorých prípadoch dokonca stúpli. Na Slovensku však tieto poplatky boli znížené.

\section{Záver}

Hospodárska sút’až ako záruka efektívnosti a pozitívneho pôsobenia na vývoj konkurencie schopnosti a stability ekonomiky je neoddelitel'nou ekonomickou a právnou kategóriou trhového mechanizmu. Pôsobí predovšetkým ako prirodzený regulátor efektívneho správania sa podnikatel'ov a súčasne vedie k optimálnemu využívaniu zdrojov. Jej miesto v ekonomike je teda nezastupitel'né. Právne je vymedzená nie len v právnych systémoch členských krajín EÚ, ale aj v komunitárnom práve. Význam práva hospodárskej sút'aže spočíva predovšetkým veliminácií vytvárania bariér na trhu výrobkov, výkonov, prác a služieb.

V oblasti elektronických komunikácií na Slovensku sa liberalizácia a vstup Slovenskej republiky do EÚ stali hlavnými faktormi prispievajúcimi k otvoreniu trhov konkurencii a vzniku alternatívnych komunikačných operátorov. Zavedenie nového regulačného rámca pre elektronické komunikácie prinieslo značný skok v rozvoji konkurencie a ochrany hospodárskej sút'aže. Avšak aj napriek tomu, že TÚ SR v súčasnosti disponuje právomocami 
umožňujúcimi uplatnit' rôzne regulačné a reštrikčné nástroje voči incumbentovi Slovak Telecom, a.s., či inému operátorovi s významným vplyvom, ešte neexistuje efektívna sút'až a dostatočná konkurencia na trhoch pevných hlasových služieb. Faktické uvol'nenie trhu by znamenalo pre všetkých zákazníkov možnost' vol'by a optimalizácie svojich nákladov, ale tiež väčšie vyhliadky na inovácie a investície v oblasti elektronických komunikačných služieb.

\section{Literatúra}

[1] ČOREJOVÁ, T. a kol.: Ekonomika sietí, EDIS - vydavatel'stvo Žilinskej univerzity, Žilina 2006, ISBN 80-8070-629-8

[2] HYŽOVÁ, J.: Hospodárska sút’až. In: Národná obroda [online], 1.marca 2004, príloha na 10. týždeň. Dostupné na: http://www.obroda.sk/clanok/4625/Hospodarska-sutaz/

[3] MADLEŇÁK, R.: Elektronický obchod. - 1. vyd. - Žilina : Žilinská univerzita, 2004. ISBN 80-8070-192-X.

[4] MAJERČÁKOVÁ, M.: Regulation in electronical communications in Slovakia and in European Union. In: Scientific Reports = Wissenschaftliche Berichte : Journal of the University of Applied Science Mittweida. - ISSN 1437-7624. - Nr. 13 (2005), p. 1-2.

[5] VACULÍK, J.: Telematické služby podl'a Rady Európy. In: Rozvoj Euroregiónu Beskydy IV: Samosprávy a európske fondy - tvorba podmienok rozvoja: zborník z medzinárodnej vedeckej konferencie. - V Žiline: Žilinská univerzita, 2006. - ISBN 80-8070-602-6. - S. 279-285.

[6] Vypočutia Európskeho parlamentu - odpovede na otázky z dotazníka pre dezignovanú komisárku Viviane Reding. Dostupné na: www.europarl.eu.int/hearings/ commission/2004_comm/pdf/speca_dimas_sk.pdf

[7] Výročná správa Protimonopolného úradu 2005

[8] Výročná správa Českého telekomunikačného úradu 2005

[9] Výročná správa Telekomunikačného úradu SR 2005

[10]Zákon č. 610/2003 Z. z. o elektronických komunikáciách

[11]Zákon č. 127/2005 Sb. o elektronických komunikacích

[12] http://www.ctu.cz/main.php?pageid=162\&PHPSESSID=3736fb1580fb063cc0de4cdc307 $\underline{\text { df140 }}$

[13] http://www.teleoff.gov.sk/sk/Sutaz/analyza.html>

\section{Grantová podpora}

Bil/Nem/SR/ŽU/06 „Pravidla dodržiavania sút’aže na trhu elektronických komunikácií“ VEGA 1/4573/07 „Možnosti, ohraničenia a vývojové tendencie koncepcie univerzálnej služby v pošte a telekomunikáciách v procese globalizácie“ 